\title{
Procruste analysis of forewing shape in two endemic honeybee subspecies Apis mellifera intermissa and $A$. $m$. sahariensis from the Northwest of Algeria
}

\author{
FOUZIA ABED ${ }^{1}$, BENABDELLAH BACHIR-BOUIADJRA ${ }^{1}$, LAHOUARI DAHLOUM ${ }^{2, \vartheta}$, \\ ABDULMOJEED YAKUBU ${ }^{3, \vee v}$, AHMED HADDAD ${ }^{1}$, ABDELKADER HOMRANI ${ }^{1}$ \\ ${ }^{1}$ Laboratoire des Sciences et Techniques de Production Animale, Abdelhamid Ibn Badis University. PO. Box 188, 27000, Mostaganem, Algeria \\ ${ }^{2}$ Laboratoire de Physiologie Animale Appliquée, Abdelhamid Ibn Badis University. PO. Box 188, 27000, Mostaganem, Algeria \\ Tel.: +213-672515273, Fax.: +213-45416827, `email: lahouari.dahloum@univ-mosta.dz \\ ${ }^{3}$ Department of Animal Science, Faculty of Agriculture, Nasarawa State University. Keffi, Shabu-Lafia Campus, P.M.B. 135, Lafia 950101, Nigeria \\ Tel.: +234-8065644748. "vemail: abdulmojyak@gmail.com
}

Manuscript received: 16 October 2020. Revision accepted: 16 December 2020.

\begin{abstract}
Abed F, Bachir-Bouiadjra B, Dahloum L, Yakubu A, Haddad A, Homrani A. 2021. Procruste analysis of forewing shape in two endemic honeybee subspecies Apis mellifera intermissa and A. m. sahariensis from the Northwest of Algeria. Biodiversitas 22: 154164. Honey bees play an important role as pollinators of many crops. Thus they are collectively considered as a veritable economic source. The present study was undertaken to describe variation in the right forewing geometry in two Algerian honeybee subspecies Apis mellifera intermissa and Apis mellifera sahariensis using landmark-based geometric morphometrics. A total of 1286 honeybees were sampled from 12 provinces in the northwest of Algeria. The forewing geometry was evaluated using 20 homologous landmarks by applying Procrustes superimposition analysis. The top four principal components accounted for only $41.1 \%$ of wing shape variation between the two subspecies. There was a significant difference in wing shape between the two subspecies (Mahalanobis distance $=$ $1.0626 ; \mathrm{P}<0.001)$, whereas their wing size seemed similar $(\mathrm{P}>0.05)$. Regarding the allometric effect, the percentage of variation in wing shape explained by size changes was relatively small, with $1.28 \%$ and $4.37 \%$ for A. m. intermissa and A.m sahariensis, respectively. The cross-validation procedure correctly classified $68.3 \%$ of specimens into their original groups. PERMANOVA test revealed significant differences in the right forewing shape among all geographic areas studied $(\mathrm{P}<0.001)$. The results clearly showed that the landmarkbased geometric approach applied to forewings venation is a powerful and reliable tool in the discrimination of native honey bee subspecies and should be considered in local honey bee biodiversity improvement and conservation initiatives.
\end{abstract}

Keywords: Apis mellifera intermissa, Apis mellifera sahariensis, forewing, geometric-morphometric, landmarks

\section{INTRODUCTION}

Besides providing hive products such as honey, royal jelly, pollen, wax, venom, and propolis (Cornara et al 2017), honeybees are important beneficial economical pollinators (Klein et al. 2007; Abdelnour et al. 2019) not only for their role in sustaining the biodiversity of agroecosystems but also in ensuring food security (Eilers et al. 2011; Klein et al. 2007). It has been reported that they pollinated more than 100 different agricultural products like fruits, vegetables, several forage plants, which eventually led to the production of meat and other dairy products (Gallai et al. 2009). However, a decline in bee populations has been recorded in some regions worldwide (Kremen and Ricketts 2000; Potts et al. 2010). This is due to several biotic and abiotic factors, including pathogens (Ullah et al. 2020), pesticides and parasites that bees met throughout their lifestyle (Henry et al. 2012; Nazzi et al. 2012); thus, their conservation recently became a global concern for both scientists and beekeepers (Byrne and Fitzpatrick 2009; Brown and Paxton 2009; Baldock et al. 2020; Freitas et al. 2009).

In order to study the genetic diversity of honeybees as a measure to help in their improvement and conservation programs, various methods have been developed to identify and to discriminate between populations, races, and even bee species and subspecies. Molecular methods including DNA analyses such as mtDNA (Arias and Sheppard 1996), RFLP (Martimianakis et al. 2011), and microsatellite DNA (Oleksa and Tofilski 2014), biochemical methods like allozymes (Bodur et al. 2007) or cuticular hydrocarbon analysis (Francis et al. 1985; Lavine et al. 2005), and other techniques based on pheromones are much less used (Hepburn and Radloff 1996). All these techniques require expensive reagents and laboratory equipment (Francoy et al. 2008). The first and the most widely accepted descriptions of subspecies were based on morphology. A wide set of morphological features have been used, including the size of various body parts, wing distances, ratios, and angles, pigmentations and pilosity (Ruttner 1988). Attempts were also made to reduce and to simplify the traditional morphometry, such as reducing the number of characters using the forewing venation alone (Francoy et al. 2008; Tofilski 2008) or using the shape of single-wing cell (Francoy et al. 2006). Geometric morphometrics (GM) is an alternative new morphometric method that used shape analysis rather than distances and angles (Bookstein 1991; Tatsuta et al. 2018). Since its first development, this 
procedure has demonstrated to be better than the traditional morphometrics not only by its low costs, high practicability but also by being less time-consuming technique, likewise having a better descriptive and higher statistical power (Charistos et al. 2014; Bustamante et al. 2020). GM uses the wing as a base of working because wings are solid and rigidly articulated structures and the intersections of the wing venation provide many well-defined landmarks suitable for the characterization and identification of populations or lineages (Pavlinov 2001; Tofilski 2008; Miguel et al. 2011; Sendaydiego et al. 2013). However, there is a paucity of research on the GM of Algerian honey bees (Barour et al. 2011; Barour et al. 2016).

The current study aimed to explore the forewing variation among two honey bee subspecies endemic to Algeria, Apis mellifera intermissa and A. m. sahariensis, using geometric morphometric tools. A. m. intermissa occupies the north of the country, while A. m. sahariensis, which is well adapted to drought conditions, is mainly located in the southern part of the country from Djebel Amour and Ain Sefra through the oasis of the Sahara south of the Atlas Mountains (Ruttner 1988; Adjlane et al. 2016). Therefore, the information obtained from the current study would be useful for implementing an effective strategy for the protection of endangered local honey bee subspecies and better management of conservation areas.

\section{MATERIALS AND METHODS}

\section{Sample sites and specimen collection}

Worker bees from 129 colonies were sampled between May and December 2018 from 12 provinces, including 63 different localities in the northwestern part of Algeria (Figure 1). Two non-migratory colonies/locality, ten bees/ colony $=20$ worker bees /locality were involved in the study. More details about the sampling sites and number of individuals collected from each sampling site are shown in Table 1. Bees were stored in $97 \%$ ethanol in a freezer ($20^{\circ} \mathrm{C}$ ) until morphological examination.

\section{Data acquisition and treatment}

A total of 1286 worker bee forewings were dissected very close to their base and were mounted in distilled water between two microscope slides and photographed with a digital camera attached to a Leica S8APO stereomicroscope. For the geometric morphometrics, wing photographs were first processed by tpsUtil 1.61 (Rohlf 2015). Wing shapes were digitized with two-dimensional Cartesian coordinates (x, y) of 20 landmarks, mainly located at vein intersections (Figure 2.A) using tpsDig 2.05 (Rohlf 2005). The landmark coordinates obtained from tpsDig were used as input in the MorphoJ 1.07a package (Klingenberg 2011). The Cartesian coordinates of the specimens were then aligned to remove variations in size, position, and orientation using the least-squares generalized Procrustes superimposition method (Bookstein 1991). In order to quantify forewing shape variation, principal component analysis (PCA) was performed after computing the variance-covariance matrix of the Procrustes shape coordinates in MorphoJ 1.07a (Klingenberg 2011).

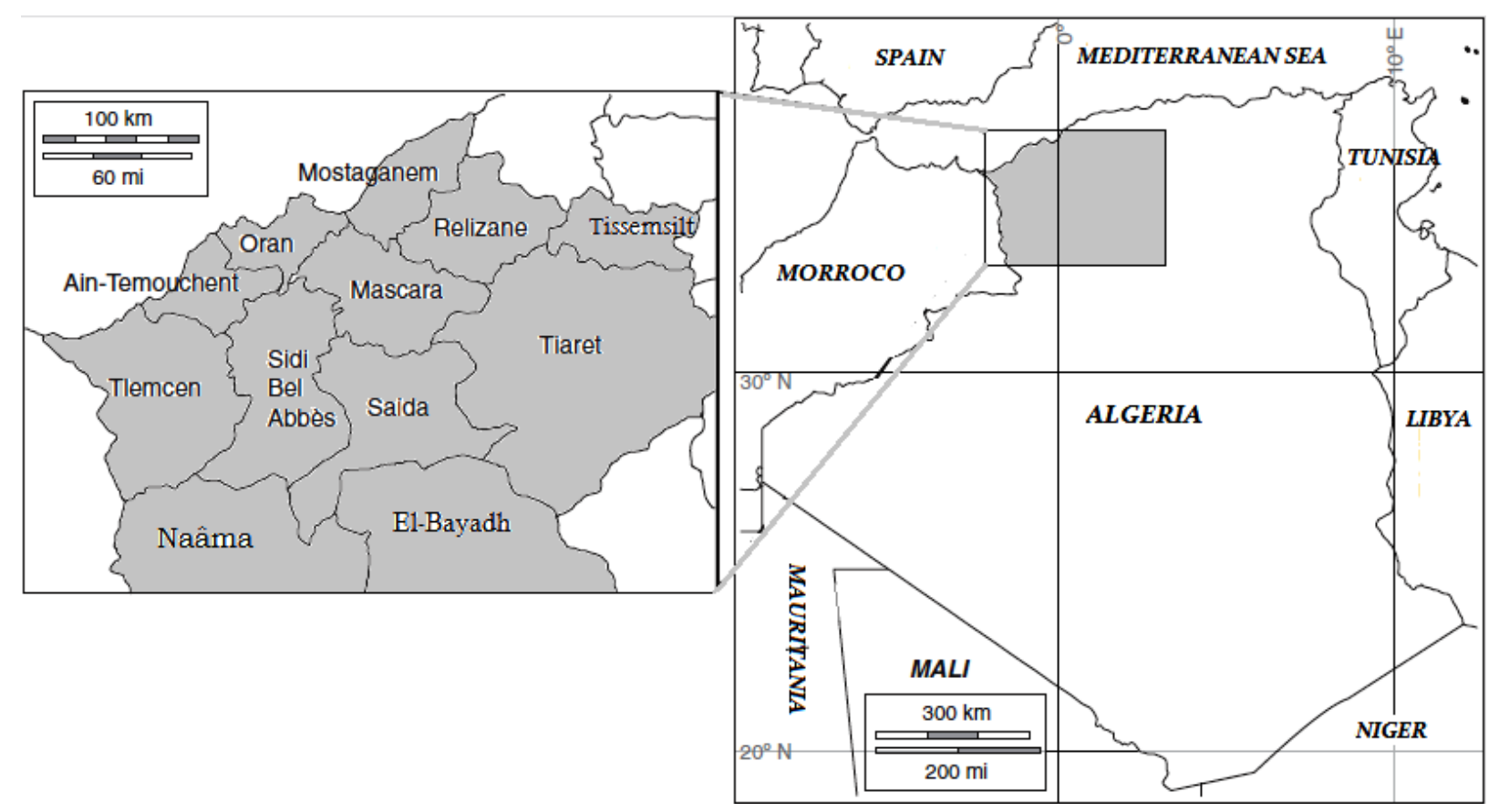

Figure 1. Map indicating sampling provinces of Apis mellifera intermissa and A. m. sahariensis in Algeria. (Adapted and modified from Mahammi et al. 2014) 
Table 1. Locations from which samples of honeybee were collected for geometric morphometric analysis

\begin{tabular}{|c|c|c|c|}
\hline Province & Sampling location & $\begin{array}{l}\text { No. of } \\
\text { colonies }\end{array}$ & $\begin{array}{l}\text { No. of } \\
\text { wings }\end{array}$ \\
\hline \multirow[t]{5}{*}{ Mascara } & Aïn Fares & 2 & 20 \\
\hline & El Guetna & 2 & 20 \\
\hline & Bou Hanifia & 2 & 20 \\
\hline & Hacine & 2 & 20 \\
\hline & Tighennif & 2 & 20 \\
\hline \multirow[t]{6}{*}{ Mostaganem } & Sour & 2 & 20 \\
\hline & Sidi Lakhdar & 2 & 20 \\
\hline & Touahria & 2 & 20 \\
\hline & Mesra & 2 & 20 \\
\hline & Hassi Mamèche & 2 & 20 \\
\hline & Souaflia & 2 & 20 \\
\hline \multirow[t]{5}{*}{ Tiaret } & Tidda & 2 & 20 \\
\hline & Aïn Bouchekif & 2 & 20 \\
\hline & Aïn Deheb & 2 & 20 \\
\hline & Tagdempt & 2 & 20 \\
\hline & Mghila & 2 & 20 \\
\hline \multirow[t]{5}{*}{ Tissemsilt } & Tamalaht & 2 & 20 \\
\hline & Sidi Abed & 2 & 20 \\
\hline & Ammari & 2 & 20 \\
\hline & Lardjem & 2 & 20 \\
\hline & Maacem & 2 & 20 \\
\hline \multirow[t]{5}{*}{ Relizane } & Oued Slam & 2 & 20 \\
\hline & El Hamadna & 2 & 20 \\
\hline & Beni Dergoun & 2 & 20 \\
\hline & Belassel & 2 & 20 \\
\hline & Zemmoura & 2 & 20 \\
\hline \multirow[t]{5}{*}{ Oran } & Boutlilis & 2 & 20 \\
\hline & Bousfer & 2 & 20 \\
\hline & Ain El Turk & 2 & 19 \\
\hline & Hassi Bounif & 2 & 20 \\
\hline & Misserghin & 2 & 19 \\
\hline \multirow[t]{5}{*}{ Saida } & Hessasna & 2 & 20 \\
\hline & Ouled Brahim & 2 & 20 \\
\hline & Balloul & 2 & 20 \\
\hline & Tirsine & 2 & 20 \\
\hline & Aïn El Hadjar & 2 & 20 \\
\hline \multirow[t]{5}{*}{ El-Bayadh } & Chellala & 2 & 20 \\
\hline & Boussemghoun & 2 & 20 \\
\hline & El Abiodh Sidi Cheikh & 2 & 18 \\
\hline & El Kheiter & 2 & 20 \\
\hline & Ghassoul & 2 & 20 \\
\hline \multirow[t]{5}{*}{ Tlemcen } & Mansourah & 2 & 20 \\
\hline & Chetouane & 2 & 20 \\
\hline & Abou Tachfine & 2 & 20 \\
\hline & Tlemcen & 2 & 20 \\
\hline & Hennaya & 2 & 20 \\
\hline \multirow[t]{7}{*}{ Sidi Belabbès } & Sidi Daho & 4 & 40 \\
\hline & Sidi Bel Abbes & 2 & 20 \\
\hline & Foret Bouhriz & 2 & 20 \\
\hline & Sidi Ali Benyoub & 2 & 20 \\
\hline & Sidi Lahcene & 2 & 20 \\
\hline & Tessala & 2 & 20 \\
\hline & Sehala Thaoura & 3 & 30 \\
\hline \multirow[t]{5}{*}{ Nâama } & Naama & 2 & 20 \\
\hline & Moghrar & 2 & 20 \\
\hline & Sfissifa & 2 & 20 \\
\hline & Tiout & 2 & 20 \\
\hline & Ain Sefra & 2 & 20 \\
\hline \multirow[t]{5}{*}{ Ain Temouchent } & Tadmaya & 2 & 20 \\
\hline & El Malah & 2 & 20 \\
\hline & El Amir Abdelkader & 2 & 20 \\
\hline & El Messaid & 2 & 20 \\
\hline & Ouled Boudjmaa & 2 & 20 \\
\hline
\end{tabular}

\section{Wing size and shape variation}

Wing size was estimated by an isometric estimator known as "centroid size" (CS) (Sandoval Ramirez et al. 2015), which is defined as the square root of the sum of the squared distances between the center of the configuration of the LM (or centroid) and each LM (Bookstein 1991). Data were tested for normality using the Shapiro-Wilk test. Levene's test was performed to check for homogeneity of variances between groups. A T-test was then used to compare the means between the two subspecies. For the analysis, the CS were logarithmized (ln CS).

The relative contributions of each anatomical landmark for the variation observed in the right forewings were produced by the tpsRelw 1.36 software package (Rohlf 2003). The Discriminant Analysis (DA) was used to classify the right-wing shapes between the subspecies studied.

Multivariate normality was assessed using the DoornikHansen test (Doornik and Hansen 2008). Box's M-test was used to test for the equivalence of the covariance matrices of the multivariate data sets as Hotelling's $\mathrm{T}^{2}$-test is sensitive to violations of the assumption of unequal covariance matrices. The statistical significance of the difference in mean shapes was then analyzed using permutation tests $(10,000$ rounds) with Mahalanobis distances and Procrustes distances. The permutation test is an alternative to Hotelling's $\mathrm{T}^{2}$-test when the assumptions of multivariate normal distributions and equal covariance matrices do not hold. Differences in wing shape among both subspecies were visualized by deformation grids using thin-plate splines (TPS) (Slice 2002). The Jackknife crossvalidated classification procedure in Discriminant Analysis (DFA) was used to assess the accuracy of classification based on Mahalanobis distances as a complement to discriminant analysis. Afterward, Mahalanobis distances among the individuals of the 12 study zones were used for the construction of a UPGMA (unweighted pair group method with the arithmetical average) dendrogram as the clustering algorithm using PAST 1.81 (Hammer et al. 2001).

\footnotetext{
Allometric effects

Allometry is the covariation of shape with size (Mosimann 1970). Morphological allometry tries to explain the change in morphological features of organisms associated with size variation (Klingenberg 1996). In insects, for example, wing size has sometimes significant impact on wing shape (Gidaszewski et al. 2009; Sontigun et al. 2017). To evaluate the allometric effect, we fitted a multivariate regression model of Procrustes coordinates (dependent variable) onto size (independent variable) among the two subspecies and within each subspecies separately in a permutation test of 10,000 randomization rounds. Centroid size was first transformed to its natural logarithm (ln centroid size) to increase the fit of the model, which was estimated by the percentage of shape variance explained by size.
} 


\section{RESULTS AND DISCUSSION}

\section{Variations in wing shape among subspecies}

The average shape obtained by the Procrustes fit of the studied subspecies is shown in Figure 2.B. The eigenvalues show that up to twenty-four PCs are needed to explain $95 \%$ of the total variation (Table 2). However, only the first ten are meaningful according to the broken-stick model (not shown). The PCA of right-wing shape variation showed that the first four PCs are responsible for only $41.11 \%$ $(\mathrm{PC} 1=11.92 \% ; \mathrm{PC} 2=10.51 \% ; \mathrm{PC} 3=9.96 \%, \mathrm{PC} 4=$ $8.72 \%)$ of the total shape variation. Although there is a clear overlap between the individuals, it is possible to observe a slight separation between the two subspecies from the scatter plot obtained using the PC1-PC2 and PC3PC4 scores (Figure 3). Moreover, the transformation grids (Figure 4) show the shape changes as a deformation of the rectangular grid. In the pooled sample of honey bees, the variance of landmark coordinates between strains revealed a discrepancy between the parts of the wing (Figure 4). Generally, LM 7 showed the maximum variation $\left(\mathrm{S}^{2}=\right.$ 0.00007) followed by LM 8, LM19, and LM3 with values of $S^{2}=0.000061,0.000039$, and 0.000038, respectively, while LM 16 (localized near the centroid of the wing) had the lowest variation of $S^{2}=0.00001$. PC1 showed that landmarks of the anterior wing region displaced toward the wing tip except for LM1, LM2, LM3, and LM7 who presented a basal displacement. Together, these landmark displacements influence the wing shape by elongation associated with narrowing. PC2 also revealed that most of the landmark points in the forewing showed deviation. The landmark displacement occurred mostly in the middle part of the wing. The anterior (LM5, LM7, and LM8) and the posterior (LM 18, LM19, and LM20) displacement resulted in a shortening linked to an expansion. The morphological characteristics of honeybees have an important role in discriminating honeybee subspecies (Salehi and NazemiRafie 2020; Henriques et al. 2020). It has been reported that different selective pressures shape morphological traits, which is crucial in evolutionary biology. Wing morphometry is among such traits that have been widely used to describe phenotypic variability at the inter-specific level (Dellicour et al. 2017). The current study results are consistent with Dolati et al. (2013), who stated that homologous anatomical landmarks located much distant from the forewing centroid had a greater degree of variations. However, the present findings contrast with those reported in Indonesia by Santoso et al. (2018). With regard to insect flight aerodynamics, long, and slender wings, according to DeVries et al. (2010) are optimal for long-duration flight, while short and broad wings are optimal for slow and agile flight.

Table 2. The first ten eigenvalues of a principal components analysis (PCA) of right forewing shape within the two subspecies Apis mellifera intermissa and A.m sahariensis

\begin{tabular}{cccc}
\hline PC & Eigenvalues & \% Variance & Cumulative \% \\
\hline 1 & 0.000083 & 11.92 & 11.92 \\
2 & 0.000073 & 10.51 & 22.43 \\
3 & 0.000069 & 9.96 & 32.39 \\
4 & 0.000061 & 8.72 & 41.11 \\
5 & 0.000051 & 7.29 & 48.41 \\
6 & 0.000044 & 6.40 & 54.81 \\
7 & 0.000037 & 5.30 & 60.11 \\
8 & 0.000032 & 4.58 & 64.69 \\
9 & 0.000027 & 3.98 & 68.67 \\
10 & 0.000026 & 3.61 & 72.28 \\
\hline
\end{tabular}

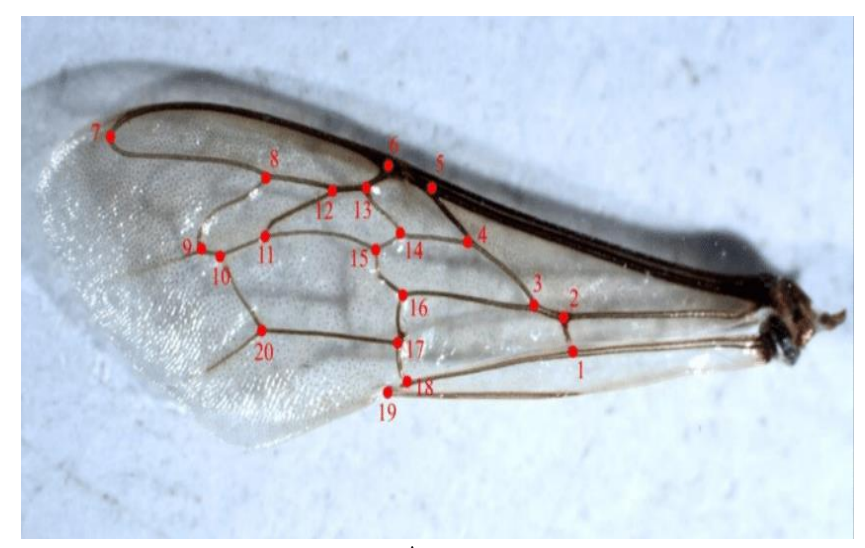

A

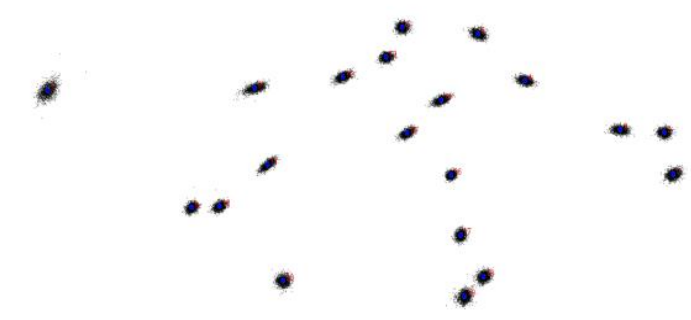

B

Figure 2.A. The Right forewing of Apis mellifera with 20 landmarks used to quantify wing shape variation. B. The landmark configurations of all wings after Procrustes superimposition. For each landmark, the blue circle indicates the location of the landmark for the average shape and the black dots indicate the locations for individual wings 

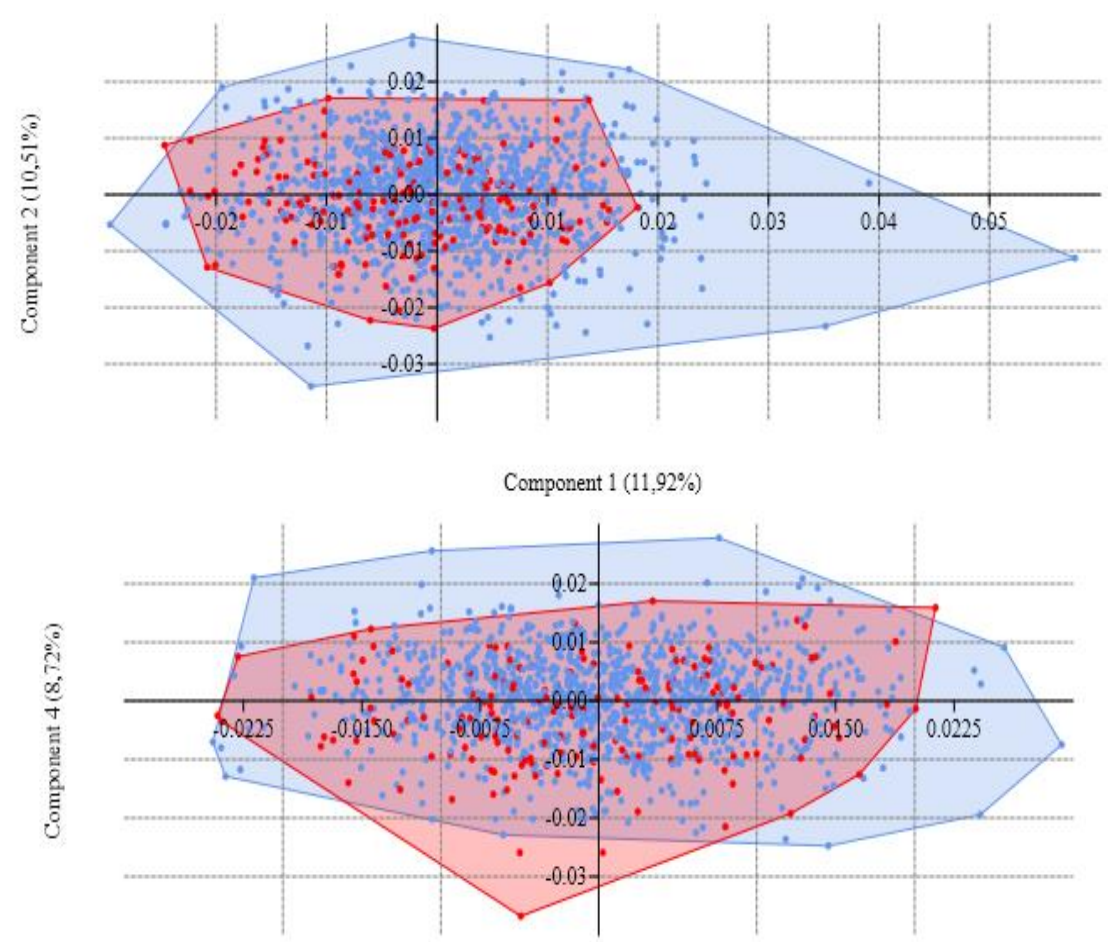

Component $3(9,96 \%)$

Figure 3. A principal component analysis (PCA) of the honey bees' right-wing configuration. A. PC1 accounted for $11.92 \%$ of the total shape variance of the total sample versus PC2, which accounted for $10.51 \%$. B. Plot of PC3 (9.96\% of total variation) and PC4 (8.72\% of total variation). $\mathrm{N}=1286$ (Apis mellifera intermissa $=1106$, A. m. sahariensis $=180$ )

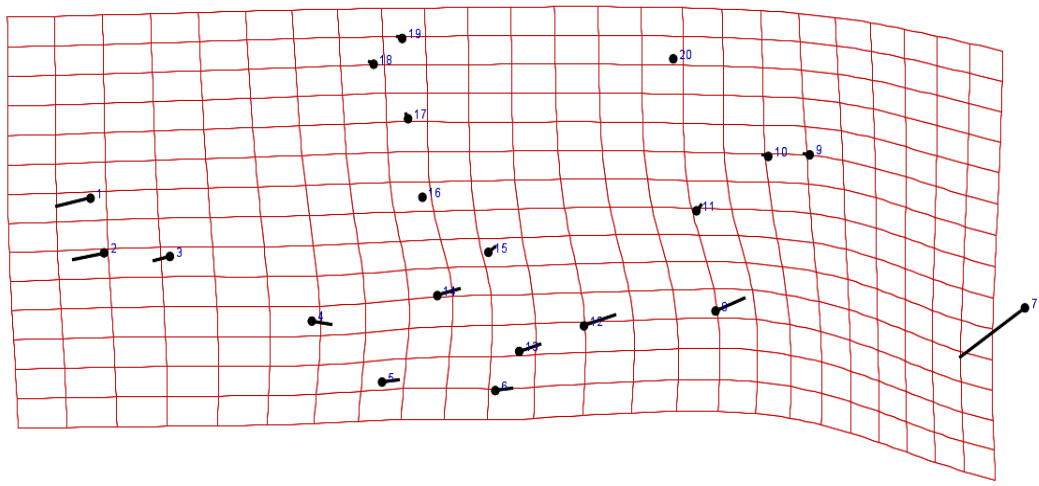

PC1

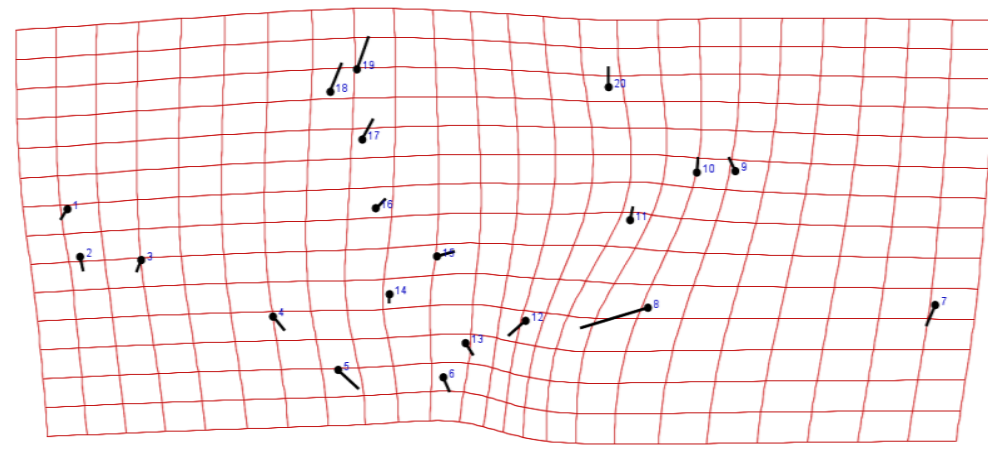

$\mathrm{PC} 2$

Figure 4. Graphs illustrating the wing shape variation in the honeybees from the western of Algeria. Deformation grids of PC1 and PC2 showing the shifts of landmark positions with straight lines with TPS. Each line starts with a dot at the landmark location in the starting shape (mean shape), The length and direction indicate the movement of the respective landmark until the target shape (scale factor $\mathrm{x} 10$ for better visibility) 


\section{Size and shape variation}

The wing size calculated base on its logarithm (log CS) was not significantly different among the two subspecies studied (T-test $=2.3023 ; \mathrm{P}=0.0214$ ) (Figure 5$)$. In this regard, the difference among the subspecies could not be explained by their wing size difference. These findings contradict the previous study by Barour et al. (2016), where very high significant differences $(\mathrm{P}<0.001)$ were found in wing centroid size between three subspecies $A . \quad m$ intermissa, A. m. sahariensis, and A. m. capensis.

The averaged shape for each of the two subspecies used in this study is shown in Figure 6. High significant difference in right-wing shape was found between $A . m$. intermissa and A. m. sahariensis (permutation test 10,000 rounds, $\mathrm{P}<0.0001$ ) (Figure 7). Mahalanobis distance (1.0626) and Procrustes distance (0.0049) obtained between the two subspecies revealed very highly significant differences (permutation test 10,000 rounds, $\mathrm{P}<0.0001$ ). The jackknife classification procedure (crossvalidation test) (Figure 8) showed that morphometric geometrics could distinguish between the two subspecies with a reliability rate of $68.3 \%$. Considering the form (size + shape), the percentage of correctly classified specimens was slightly increased to $69.3 \%$, which is consistent with the report of Barour et al. (2011). However, the findings of the current study are lower than the $99.5 \%$ and $79 \%$ reported by Salehi and Nazemi-Rafie (2020) and Kandemir et al. (2011), respectively. The accuracy classification can be improved even slightly, integrating other features of selection such as a hind wing or number of Hamuli (Barour et al. 2016). Additionaly, Francoy et al. (2012) reported a significant increase in classification success when contour and landmark methodologies were combined. Furthermore, images of bees' wings in conjunction with computer vision and artificial intelligence techniques can be used to automate and facilitate the identification process of bee species (Fagundes et al. 2020). Similarly, Silva (2015) highlighted that the use of conjunction of morphometric and pixel-based features is more effective than only using morphometric features for discriminating species of bees.

\section{Allometric effect}

In the current study, the regression of the Procrustes coordinates on Log centroid size among subspecies (Figure 9) showed a highly significant difference (permutation test 10,000 rounds, $P<0.0001$ ), but only $1.43 \%$ of total wing shape variation was explained by allometry. Moreover, the relationship between shape and size within each species showed that wing shape variation was significantly correlated to size in the two subspecies (permutation test with 10,000 rounds, $P<0.0001$ ). Although the regression of shape variation on size was significant, the percentage of variation in wing shape explained by size changes was relatively small with $1.28 \%$ and $4.37 \%$ for $A$. m. intermissa and $A$. m. sahariensis, respectively. The present findings are consistent with the previous reports of Barour et al. (2011). During a GPA, only the isometric effects are removed, not the allometric effects (Outomuro and Johansson 2017). According to Skandalis et al. (2017), the proper understanding of the origin of wing area allometry and how it influences flight performance has the potential to explain the diversification of organisms into their specialized ecological niche, including the general biomechanical evolution of flying animals.

\section{Variations in wing size and shape among localities}

The Shapiro-Wilk test revealed a normal distribution in the right forewing size in all provinces $(\mathrm{P}>0.05)$. Results of One-way ANOVA of the mean forewing $\log C$ S (Table 3) showed significant differences among colonies from the twelve geographical localities $(\mathrm{F}=24.02, \mathrm{P}=0.0001)$. The highest centroid size value was recorded in Tlemcen, while the smallest wing size was found in Tissemsilt and Relizane. Furthermore, the coefficient of variation of forewing size ranged from $24.1 \%$ to $40.7 \%$, indicating relative homogeneity or heterogeneity of the honey bee populations. Overall, the current findings are consistent with the reports of Barour et al. (2011) and Prado-Silva et al. (2016). In Iraq, Sultan (2015) reported no significant differences in the size and shape of the right front wings of honeybee worker A.mellifera collected from two distinct geographic areas of Baghdad and Diyala.

The Doornik-Hansen test for multivariate normality revealed that the shape data in all geographic areas were not normally distributed. Box's M-test revealed heterogeneity of the variance-covariance matrices for right forewing shape variables $(\mathrm{F}=1.259, \mathrm{P}<0.0001)$. Results of the non-parametric MANOVA-test (PERMANOVA) showed highly significant differences in the right forewing shape among the twelve geographic areas studied ( $\mathrm{F}=$ 6.394, $\mathrm{P}<0.0001$, permutation $\mathrm{N}=10,000$ ). Post-hoc pairwise comparisons revealed significant differences $(\mathrm{P}<0.01)$ among all study zones except between Mostaganem and Saida provinces $(\mathrm{P}>0.05)$. Prado-Silva et al.(2016) also reported significant effect of geographic zone in forewing shape of Melipona mandacaia.

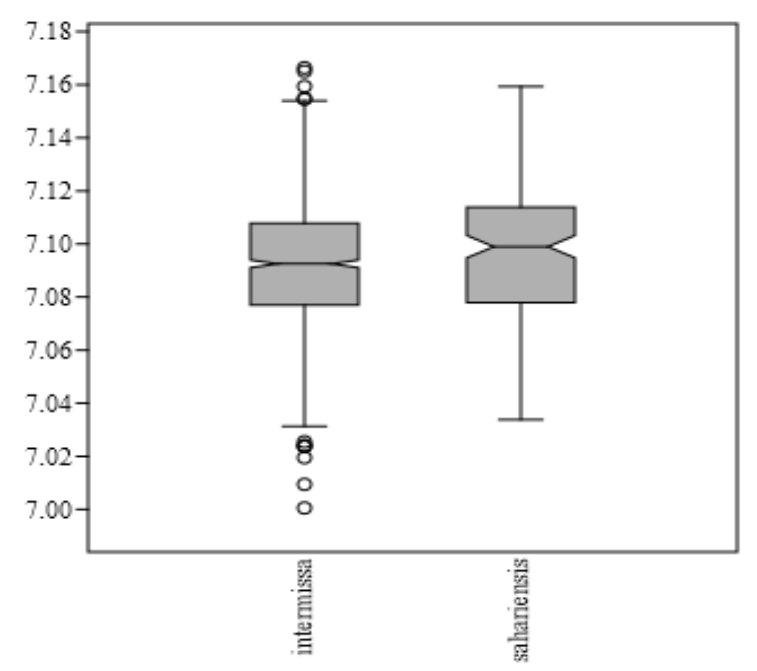

Figure 5. Box plot showing log centroid size of right wings for Apis mellifera intermissa and A.m. sahariensis $(\mathrm{P}=0.214)$. Circles mark the atypical values of CS 


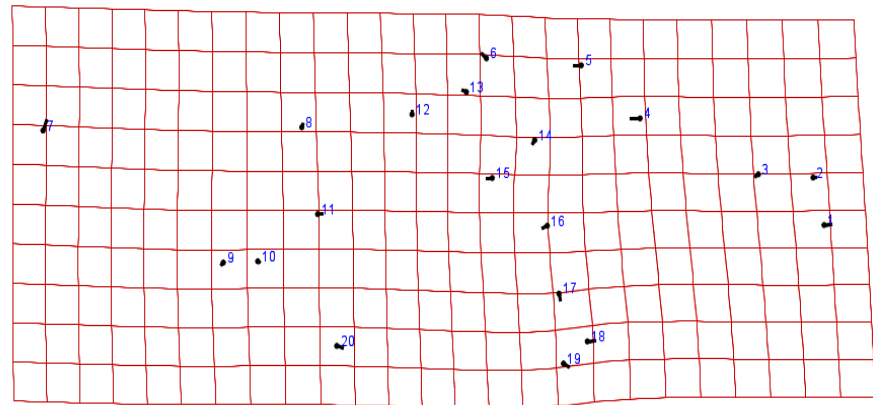

intermissa

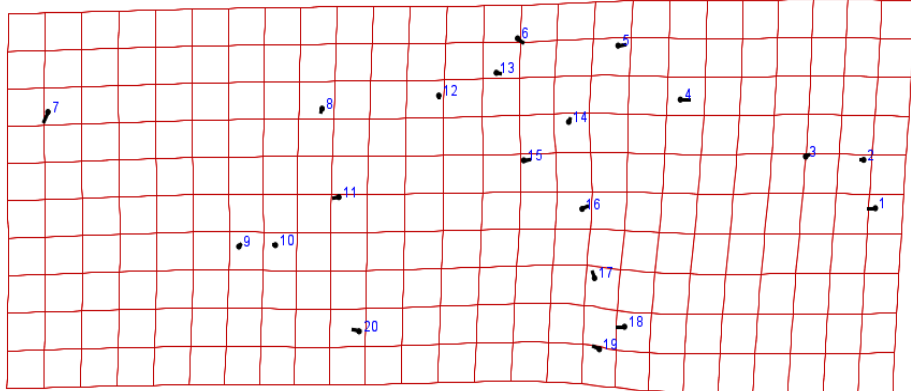

sahariensis

Figure 6. The thin-plate spline grid showing the averaged forewing shape for Apis mellifera intermissa (above) and A.m. sahariensis (below) (scale factor $\mathrm{x} 10$ for better visibility)

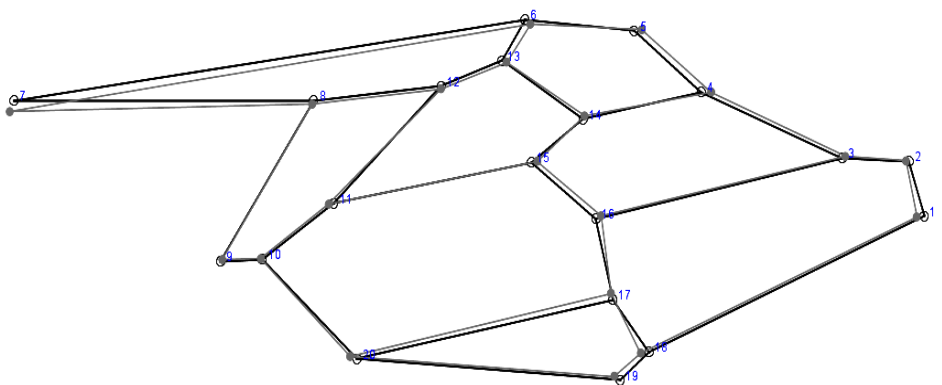

intermissa -- sahariensis

Figure 7. Wireframe scheme showing the forewing shape differences between Apis mellifera intermissa and A. m. sahariensis using MorphoJ. Blackline for the positive side and grey and line for the negative side of the canonical (Scale factor $\mathrm{x} 5$ for better visibility of the shape differences)

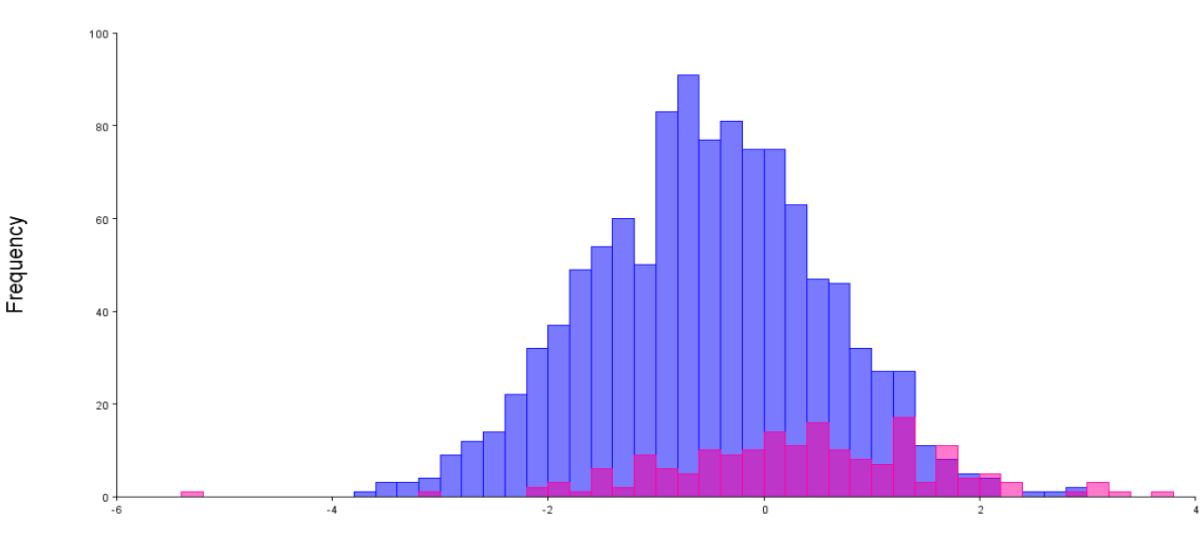

intermissa -- sahariensis

Figure 8. Results of the cross-validation test for the discriminant function in wing shape between Apis mellifera intermissa and A. $m$ sahariensis subspecies 


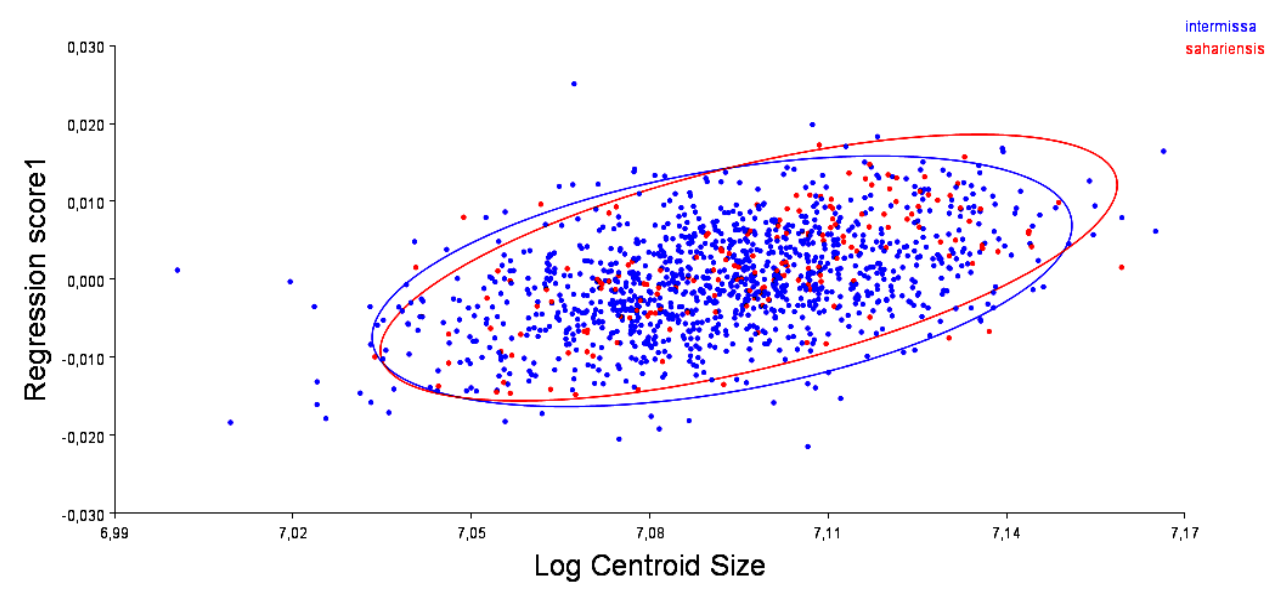

Figure 9. Multivariate regression scores of the wing Procrustes shape coordinates by log centroid size with 95\% confidence ellipses

Table 3. Mean, standard deviation and coefficient of variation $(\%)$ of log centroid size for each study province

\begin{tabular}{lllll}
\hline Locality & $\mathbf{N}$ & LogCS & SD & CV (\%) \\
\hline Tlemcen & 99 & $7.107^{\mathrm{g}}$ & 0.022 & 30.4 \\
Tiaret & 100 & $7.092^{\text {cde }}$ & 0.024 & 33.2 \\
Saida & 100 & $7.105^{\mathrm{g}}$ & 0.017 & 24.1 \\
Sidi Belabbès & 170 & $7.098^{\mathrm{defg}}$ & 0.023 & 25.0 \\
Mostaganem & 120 & $7.089^{\mathrm{bcd}}$ & 0.018 & 36.9 \\
Mascara & 99 & $7.087^{\mathrm{bc}}$ & 0.026 & 35.4 \\
Oran & 98 & $7.101^{\mathrm{efg}}$ & 0.025 & 32.3 \\
El-Bayedh & 100 & $7.082^{\mathrm{ab}}$ & 0.023 & 29 \\
Tissemsilt & 100 & $7.076^{\mathrm{a}}$ & 0.021 & 29.3 \\
Nâama & 100 & $7.103^{\mathrm{fg}}$ & 0.021 & 23.5 \\
Ain Temouchent & 100 & $7.093^{\mathrm{cdef}}$ & 0.017 & 40.7 \\
Relizane & 100 & $7.076^{\mathrm{a}}$ & 0.029 & \\
\hline
\end{tabular}

Note: Values with different superscript letters are significantly different $(\mathrm{P}<0.001)$, SD: standard deviation, CV: coefficient of variation

The first five axes of the canonical variate analysis (CVA) exhibited nearly $76 \%$ of the variation in forewing shape between the geographical zones (Table 4). However, the forewing shapes of the populations were not clearly distinguished on all scatter plots (not shown), and no cluster population-based on wing shape was identified. Charistos et al. (2014) also reported that the CVA and the PCA results appeared to detect differences between the honey bee populations from Greece. In their study, Dolati et al. (2013) highlighted that front wing measures discriminated area populations better than hind wing measures using a geometric morphometric method and further reported that populations with small geographical distances had more morphological similarities. Nonetheless, Prado-Silva et al. (2016) reported no significant morphometric differences in Melipona mandacaia in relation to altitude, but both fore wing size and shape were correlated to geographic distance.

Based on the locality level, the cross-validation test showed low percentages of correctly classified specimens ranging from $23 \%$ to $46.5 \%$ in all provinces studied (Table 5). These values are lower than the correct identification rate of $68.2 \%$ obtained for European honey bee populations from nine geographical zones in Iran (Dolati et al. 2013). The differences observed could be due to genetic, environmental, and abiotic factors, which according to Dolati et al. (2013) could influence wing shape. Also, the overlapping in the PCA results and the low rate of correct classification may indicate of hybridization between regions with a possible gene flow. Therefore, further studies must be taken into account, as the genetic divergence hypothesis appears to be appropriate not only at the horizontal level of northeast, north-middle and northwest of Algeria, but also at the northern, central and southern Algeria vertical level.

Table 4. The first five canonical variates for the discrimination of the 12 honey bee populations.

\begin{tabular}{llll}
\hline CV & Eigenvalues & \% Variance & \% Cumulative \\
\hline 1 & 0.407209 & 21.940000 & 21.940000 \\
2 & 0.336480 & 18.129000 & 40.069000 \\
3 & 0.306446 & 16.511000 & 56.579000 \\
4 & 0.209595 & 11.293000 & 67.872000 \\
5 & 0.150482 & 8.108000 & 75.980000 \\
\hline
\end{tabular}


Table 5. Percentage of correctly classified specimens in each city performed using a permutation test with 10,000 rounds

\begin{tabular}{lc}
\hline Locality & $\begin{array}{c}\text { \% correctly classified } \\
\text { (No. of correctly classified/ Total no. of } \\
\text { specimens) }\end{array}$ \\
\hline Tlemcen & $46.5 \%(46 / 99)$ \\
Tiaret & $23 \%(23 / 100)$ \\
Saida & $26 \%(26 / 100)$ \\
Sidi Belabbès & $30.6 \%(52 / 170)$ \\
Mostaganem & $43.3 \%(52 / 120)$ \\
Mascara & $25.3 \%(25 / 99)$ \\
Oran & $43.9 \%(43 / 98)$ \\
El-Bayedh & $28 \%(28 / 100)$ \\
Tissemsilt & $34 \%(34 / 100)$ \\
Nâama & $45 \%(45 / 100)$ \\
Ain Temouchent & $41 \%(41 / 100)$ \\
Relizane & $35 \%(35 / 100)$ \\
Overall \% & $34.8 \%$ \\
\hline
\end{tabular}

According to the UPGMA dendrogram showing phenetic relationships of forewing morphology based on the Mahalanobis distances between the 12 geographical localities under study, there were two main clusters initially (Figure 10). Tiaret and Naama provinces (highlands zone) were categorized into the first cluster. All the remaining provinces representing different agro-ecological zones (highlands, plains, and coastal zone) belonged to the second cluster. This suggests that geographic obstacles play no significant role in controlling the two subspecies' geographic repartition. These findings are in agreement with what was reported in Romania by Coroian et al (2014), where the Carpathians mountains had only limited impact on the biogeography of both A. m. carnica and A. $m$. macedonica subspecies. However, subspecies differentiation according to the same authors, strongly correlated with the various temperature zones. Similarly Rattanawannee et al. (2012) found no clear separation of Apis dorsata populations collected from five principal geographic locations in mainland Thailand. In the northwestern Algerian area under study, the Ruttner's classification (Ruttner1988) referred subspecies is thus no longer recognized. It has been reported that migratory beekeeping can form differences within populations (Arias et al. 2006; Marghitas et al. 2008). The unregulated movements of beekeeping, trading colonies and importing queens are all dangerous activities for beekeeping. Honeybee biodiversity must therefore be maintained through some creative approaches such as setting up conservation areas for the native subspecies, fertilization stations, and even using artificial insemination to mitigate the impact of polyandry for queens. This may help beekeepers eliminate colonies that differ the most from their preferred native subspecies (Nawrocka et al. 2018).

In conclusion, this study evidenced that geometric morphometrics using the forewing proved to be a useful tool in discriminating the two native subspecies of Algeria A. m. intermissa and A. m.sahariensis. Moreover, in the present research, the results showed that Ruttner classification is no longer respected, and geographic barriers seem to be unreliable in protecting the natural distribution of the two subspecies. Further exploration based on genetic markers is necessary to determine the contribution of genetic differentiation in the morphological findings.

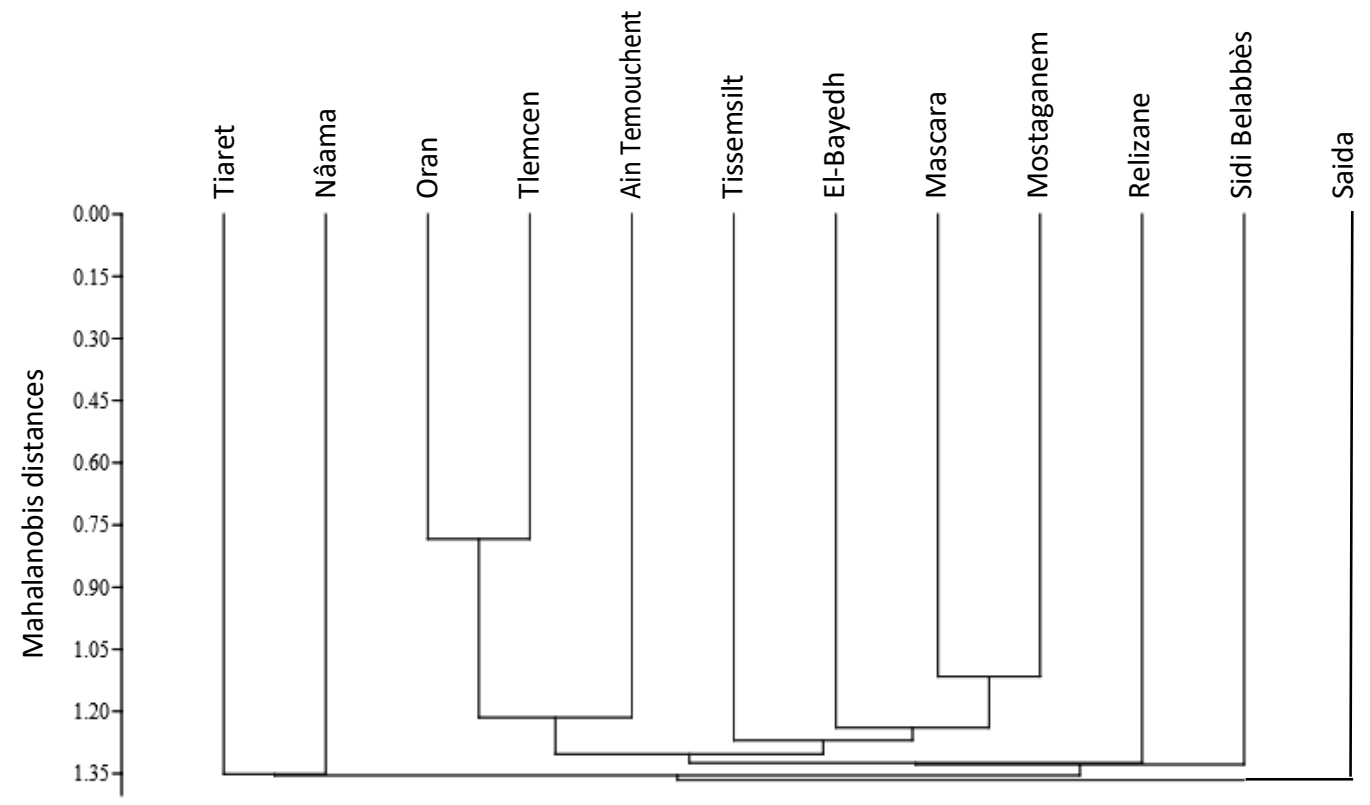

Figure 10. A dendrogram produced by the Unweighted Pair-Group method (UPGMA) showing phenetic relationships of forewing morphology based on the Mahalanobis distances between the 12 geographical localities 


\section{ACKNOWLEDGEMENTS}

We gratefully acknowledge the beekeepers for politely providing the bee samples. Particular thanks go to İrfan Kandemir from the Department of Biology, Faculty of Science, Ankara University, Tandoğan, Turkey, for his help with landmark digitalization. We also wish to thank La Direction Générale de la Recherche Scientifique et du Développement Technologique, Algeria for the financial support of the study.

\section{REFERENCES}

Abdelnour SA, Abd El-Hack ME, Alagawany M, Farag MR, Elnesr SS. 2019. Beneficial impacts of bee pollen in animal production, reproduction and health. J Anim Physiol Anim Nutr 103: 477-484 DOI: 10.1111/jpn.13049.

Adjlane N, Dainat B, Gauthier L. Dietemann V. 2016. Atypical viral and parasitic pattern in Algerian honey bee subspecies Apis mellifera intermissa and A. m. sahariensis. Apidologie (47): 631-641 DOI: 10.1007/s13592-015-0410-x.

Arias MC, Rinderer TE, Sheppard WS. 2006. Further characterization of honeybees from the Iberian peninsula by allozyme, morphometric and mtDNA haplotype analyses. J Apic Res 45 (4): 188-196.

Arias MC, Sheppard WS. 1996. Molecular phylogenetics of honey bee subspecies (Apis mellifera L.). Mol. Phylogenet. Evol. 5: 557-566.

Baldock K CR. 2020. Opportunities and threats for pollinator conservation in global towns and cities. Curr Opin Insect Sci (38): 63-71. DOI: 10.1016/j.cois.2020.01.006.

Barour C, Baylac M. 2016. Geometric morphometric discrimination of the three African honeybee subspecies Apis mellifera intermissa, A. m. sahariensis and A. m. capensis (Hymenoptera, Apidae): Fore wing and hind wing landmark configurations. J Hymenopt Res 52: 61-70. DOI: $10.3897 / \mathrm{jhr} .52 .8787$

Barour C, Tahar A, Baylac M. 2011. Forewing shape variation in Algerian honeybee populations of Apis mellifera intermissa (Buttel-Reepen, 1906) (Hymenoptera: Apidae): A landmark based geometric morphometrics analysis. Afr Entomol 19 (1): 11-22. DOI: 10.4001/003.019.0101

Bodur C, Kence M, Kence A. 2007. Genetic structure of honeybee, Apis mellifera L. (Hymenoptera: Apidae) populations of Turkey inferred from microsatellite analysis. J Apic Res (46): 50-56.

Bookstein FL. 1991. Morphometric Tools for Landmark Data: Geometry and Biology. Cambridge University Press, New York: 435 pp.

Brown, MJF, Paxton RJ. 2009. The conservation of bees: a global perspective. Apidologie 40: 410-416. DOI: 10.1051/apido/2009019.

Bustamante T, Baiser B, Ellis JD. 2020. Comparing classical and geometric morphometric methods to discriminate between the South African honey bee subspecies Apis mellifera scutellata and Apis mellifera capensis (Hymenoptera: Apidae). Apidologie (Celle) 51: 123-136. DOI: 10.1007/s13592-019-00651-6.

Byrne A, Fitzpatrick Ú. 2009. Bee conservation policy at the global, regional and national levels. Apidologie 40 (3): 194-210. DOI: 10.1051/apido/2009017.

Charistos L, Hatjina F, Bouga M, Mladenovic M, Maistros A 2014. Morphological DISCRIMINATION of Greek honey bee populations based on geometric morphometrics analysis of wing shape. J Api Sci 58 (1): 75-84. Doi: 10.2478/jas-2014-0007.

Cornara L, Biagi M, Xiao J, Burlando B. 2017. Therapeutic Properties of Bioactive Compounds from Different Honeybee Products. Front Pharmacol 8: 412. DOI: 10.3389/fphar.2017.00412.

Coroian CO, Muñoz I, Schlüns EA, Paniti-Teleky OR, Erler S, Furdui EM, Mărghitaş LA, Dezmirean DS, Schlüns H, De la Rúa P, Moritz RFA. 2014. Climate rather than geography separates two European honeybee subspecies. Mol Ecol 23 (9): 2353-2361. DOI 10.1111/mec.12731

Dellicour S, Gerard M, Prunier JG, Dewulf A, Kuhlmann M, Michez D. 2017. Distribution and predictors of wing shape and size variability in three sister species of solitary bees. PloS One 12 (3): e0173109. DOI: 10.1371/journal.pone.0173109.
DeVries PJ, Penz CM, Hill RI. 2010. Vertical distribution, flight behaviour and evolution of wing morphology in Morpho butterflies: Wing evolution in Morpho butterflies. J Anim Ecol 79: 1077-1085.

Dolati L, NazemiRafie J, Khalesro H. 2013. Landmark-based morphometric study in the fore and hind wings of an Iranian Race of European honeybee (Apis mellifera meda). J Apic Sci 57: 187-197.

Doornik JA, Hansen H. 2008. An omnibus test for univariate and multivariate normality. Oxf Bull Econ Stat 70: 927-939.

Eilers EJ, Kremen C, Greenleaf SS, Garber AK, Klein, A-M. 2011. Contribution of pollinator-mediated crops to nutrients in the human food supply. PLoS One 6 (6): e21363. DOI: 10.1371/journal.pone.0021363.

Fagundes J, Rebelo A, Digiampietri L, e Bíscaro H. 2020. Fully automatic segmentation of bee wing images. Revista Brasileira de Computação Aplicada 12 (2): 37-45. DOI: 10.5335/rbca.v12i2.10420.

Francis BR, Blanton WE, Nunamaker RA. 1985. Extractable surface hydrocarbons of workers and drones of the genus Apis. J Apic Res 24: 13-26.

Francoy TM, Faria Franco F, Roubik DW. 2012. Integrated landmark and outline-based morphometric methods efficiently distinguish species of Euglossa (Hymenoptera, Apidae, Euglossini). Apidologie (Celle) 43: 609-617. DOI: 10.1007/s13592-012-0132-2.

Francoy TM, Imperatriz-Fonseca VL. 2010. A morfometria geométricade asas e a identifiação automática de espécies de abelhas. Oecologia Aust 14 (1): 317-321.

Francoy TM, Prado PRR, Goncalves LS, Costa LF, DeJong D. 2006. Morphometric differences in a single wing cell can discriminate Apis mellifera racial types. Apidologie 37: 91-97.

Francoy TM, Wittmann D, Drauschke M, Müller S, Steinhage V, BezerraLaure MAF, De Jong D, Gonçalves LS. 2008. Identification of Africanized honey bees through wing morphometrics: two fast and efficient procedures. Apidologie 39: 488-494.

Freitas BM, Imperatriz-Fonseca VL, Medina LM, Kleinert ADP, Galetto L, Nates-Parra G, Quezada-Euan JJG. 2009. Diversity, threats and conservation of native bees in the Neotropics. Apidologie 40: 332 346.

Gallai N, Salles J-M, Settele J, Vaissière BE. 2009. Economic valuation of the vulnerability of world agriculture confronted with pollinator decline. Ecol Econ 68 (3): 810-821. DOI: 10.1016/j.ecolecon.2008.06.014ff.

Gidaszewski, NA, Baylac M, Klingenberg CP. 2009. Evolution of sexual diimorphism of wing shape in the Drosophila melanogaster subgroup. BMC Evol Biol 9: 110. DOI: 10.1186/14712148-9-110.

Hammer $\varnothing$, Harper DAT, Ryan PD. 2001. PAST: Paleontological statistics software package for education and data analysis. Palaeontol Electron 4: 9 .

Henriques D, Chávez-Galarza J, Teixeira JSG, Ferreira H, Neves CJ, Francoy TM, Pinto MA. 2020. Wing geometric morphometrics of workers and drones and single nucleotide polymorphisms provide similar genetic structure in the Iberian honey bee (Apis mellifera iberiensis). Insects 11 (2): 89. DOI: 10.3390/insects11020089.

Henry M, Béguin M, Requier F, Rollin O, Odoux JF, Aupinel P, Aptel J, Tchamitchian S, Decourtye A. 2012. A common pesticide decreases foraging success and survival in honey bees. Science 336 (6079): 348-350.

Hepburn HR, Radloff SE. 1996. Morphometric and pheromonal analyses of Apis mellifera L. along a transect from the Sahara to the Pyrenees. Apidologie 27 (1): 35-45. DOI: 10.1051/apido:19960105.

Kandemir I, Özkan A, Fuchs S. 2011. Reevaluation of honeybee (Apis mellifera) microtaxonomy: A geometric morphometric approach Apidologie (Celle) 42: 618-627. DOI: 10.1007/ s13592-011-0063-3.

Klein AM, Vaissiere BE, Cane JH, Steffan-Dewenter I, Cunningham SA, Kremen C, Tscharntke T. 2007. Importance of pollinators in changing landscapes for world crops. Proc R Soc B Biol Sci 274 (1608): $303-$ 313.

Klingenberg CP. 1996. Multivariate Allometry. Adv Morphometrics. DOI: $10.1007 / 978-1-4757-9083-2 \_3$

Klingenberg CP. 2011. MorphoJ: An integrated software package for geometric morphometrics. Mol Ecol Resour 11: 353-357.

Kremen C, Ricketts T. 2000. Global perspectives on pollination disruptions. Conserv Biol 14: 1226-1228.

Lavine BK, Vora MN. 2005. Identification of Africanized honeybees. J Chromatog A 1096: 69-75. DOI: 10.1016/j.chroma.2005.06.049.

Lima Jùnior CA, Carvalho CAL, Nunes LA, Francoy TM. 2012. Population divergence of Melipona scutellaris (Hymenoptera: 
Meliponina) in two restricted areas in Bahia, Brazil. Sociobiology 59 (1): 107-122. DOI: 10.13102/sociobiology.v59i1.670.

Mahammi FZ, Gaouar SBS, Tabet-Aoul N, Tixier-Boichard M, SaïdiMehtar N. 2014. Caractéristiques morpho-biométriques et systèmes d'élevage des poules locales en Algérie occidentale (Oranie). Cah Agric (23): 382-392. DOI: 10.1684/agr.2014.0722

Marghitas AL, Paniti-Teleky O, Dezmirean D, Rodica M, Cristina B, Coroian C, Laura L, Adela M. 2008. Morphometric differences between honeybees (Apis mellifera carpatica) populations from Transylvanian area. Lucrări ştiinifice-Zootehnie şi Biotehnologii 41 (2): $309-315$

Martimianakis S, Klossa-Kilia, Bouga M, George K. 2011. Phylogenetic relationships of Greek Apis mellifera subspecies based on sequencing of mtDNA segments (COI and ND5). J Apic Res 50 (1): 4250. DOI: 10.3896/IBRA.1.50.1.05.

Miguel I, Baylac M, Iriondo M, Manzano C, Garney L, Estonba A. 2011. Both geometric morphometrics and microsatellite data support the differenciation of the Apis mellifera $\mathrm{M}$ evolutionary branch. Apidologie (Celle) 42 (2): 150-161. DOI: 10.1051/apido/2010048.

Mosimann JE. 1970. Size allometry: size and shape variables with characterizations of the lognormal and generalized gamma distributions. J Am Stat Assoc (65): 930-945. DOI:10.2307/2284599.

Nawrocka A, Kandemir İ, Fuchs S, Tofilski A. 2018. Computer software for identification of honey bee subspecies and evolutionary lineages. Apidologie (Celle) 49: 172-184. DOI: 10.1007/s13592-017-0538-y. DOI: $10.1007 / s 13592-017-0538-y$

Nazzi F, Brown S P, Annoscia D, Del Piccolo F, Di Prisco G, Varricchio P, Vedova GD, Cattonaro F, Caprio E, Pennacchio F. 2012. Synergistic parasite-pathogen interactions mediated by host immunity can drive the collapse of honeybee colonies. PLoS Pathogens 8 (6): DOI: 10.1371/journal.ppat.1002735.

Oleksa A, Tofilski A. 2014. Wing geometric morphometrics and microsatellite analysis provide similar discrimination of Honey Bee subspecies. Apidologie (Celle) 46: 49-60. DOI: 10.1007/s13592-0140300-7.

Outomuro D, Johansson FA. 2017. Potential pitfall in studies of biological shape: Does size matter? J Anim Ecol 86: 1447-1457. DOI: 10.1111/1365-2656.12732.

Pavlinov IY. 2001. Geometric morphometrics, a new analytical approach to comparision of digitized images. Information Technology in Biodiversity Research: Abstracts of the 2nd International Symposium. St. Petersburg: Russian Academy of Science, 44-64.

Potts SG, Biesmeijer JC, Kremen C, Neumann P, Schweiger O, Kunin WE. 2010. Global pollinator declines: trends, impacts and drivers, Trends Ecol Evol 25 (6): 345-353. DOI: 10.1016/j.tree.2010.01.007.

Prado-Silva A, Nunes LA, De Oliveira Alves RM, Carneiro PLS, Waldschmidt AM. 2016. Variation of fore wing shape in Melipona mandacaia Smith, 1863 (Hymenoptera, Meliponini) along its geographic range. $\mathrm{J}$ Hymenopt Res 48: 85-94. DOI: 10.3897/JHR.48.6619.

Rattanawannee A, Chanchao C, Wongsiri S. 2012. Geometric morphometric analysis of giant honeybee (Apis dorsata Fabricius, 1793) populations in Thailand. J Asia Pac Entomol 15 (4): 611-618.
Rohlf FJ. 2003. tpsRelw-Relative Warp Analysis, version 1.36. Stony Brook University, Stony Brook, NY.

Rohlf FJ. 2005. tpsDig, digitize landmarks and outlines, version 2.05 Department of Ecology and Evolution. State University of New York at Stony Brook, NY.

Rohlf FJ. 2015. tpsUtil, file utility program. version 1.61. Department of Ecology and Evolution. State University of New York at Stony Brook, NY.

Ruttner F. 1988. Biogeography and Taxonomy of Honeybees. Springer, Berlin.

Salehi S, Nazemi-Rafie J. 2020. Discrimination of Iranian honeybee populations (Apis mellifera meda) from commercial subspecies of Apis mellifera L. using morphometric and genetic methods. J Asia Pac Entomol 23: 591-598. DOI: 10.1016/j.aspen.2020.04.009.

Sandoval Ramirez CM, Nieves Blanco EE, Gutiérrez Marin R, Jaimes Mendez DA, Rodríguez NO, Otálora-Luna F, Aldana, E. J. 2015. Morphometric analysis of the host effect on phenotypical variation of Belminus ferroae (Hemiptera: Triatominae). Psyche: 1-12. DOI: $10.1155 / 2015 / 613614$

Santoso MAD, Juliandi B, Raffiudin R. 2018. Honey bees species differentiation using geometric morphometric on wing venations. IOP Conf Ser: Earth Environ Sci 197: 012015. DOI: 10.1088/17551315/197/1/012015.

Sendaydiego JP, Torres MAJ, Demayo CG. 2013. Describing wing geometry of Aedes aegypti using landmark-based geometric morphometrics. Intl J Biosci Biochem Bioinformatics 3 (4): 33793383.

Silva F. 2015. Automated Bee Species Identification through Wing Images. [Thesis]. University of Sao Paulo. [Brazilian].

Skandalis DA, Segre PS, Bahlman JW, Groom DJE, Welch Jr, KCW, Witt CC, McGuire JA, Dudley R, Lentink D, Altshuler DL. 2017. The biomechanical origin of extreme wing allometry in humming birds. Nat Commun 8: 1047. DOI: 10.1038/s41467-017-01223-x.

Slice DE. 2002. Morpheus, for morphometric research software. Department of Biomedical Engineering, Wake Forest University School of Medicine, Winston, Salem.

Sontigun N, Sukontason KL, Zajac B, Zehner R, Sukontason K, Wannasan A, Amendt J. 2017. Wing morphometrics as a tool in species identification of forensically important blow flies of Thailand. Parasit Vectors 10: 229. DOI:10.1186/s13071-017-2163-Z

Sultan AA. 2015. Studying the variation of wing shape and size for Iraqi honey bee worker Apis mellifera (Hymenoptera: Apidae) collected from Baghdad and Diyala provinces by using geometric morphometric of wing. Intl J Curr Res 7 (1): 11319-11324.

Tatsuta H, Takahashi KH, Sakamaki Y. 2018. Geometric morphometrics in entomology: Basics and applications. Entomol Sci 21 (2): 164-184. DOI: $10.1111 /$ ens.12293. DOI: $10.1111 /$ ens. 12293.

Tofilski A. 2008. Using geometric morphometrics and standard morphometry to discriminate three honeybee subspecies. Apidologie (Celle) 39: 558-563. DOI: 10.1051/apido:2008037.

Ullah A, Tlak Gajger I, Majoros A, et al. 2020. Viral impacts on honey bee populations: A review. Saudi J Biol Sci. DOI: 10.1016/j.sjbs.2020.10.037. 